\title{
A Narrative Review of Factors Affecting Job Satisfaction among Nurses in Africa
}

\author{
Emmanuel Ajuluchukwu Ugwa ${ }^{1}$, Ugwa Charity ${ }^{2}$ \\ ${ }^{1}$ Obstetrics/Gynaecology Department, Federal Medical Centre, Birnin Kudu, Jigawa State, Nigeria \\ ${ }^{2}$ Nursing Services Department, Aminu Kano Teaching Hospital, Kano, Nigeria
}

*Corresponding Author: Emmanuel Ajuluchukwu Ugwa, MD, Obstetrics/Gynaecology Department, Federal Medical Centre, Birnin Kudu, Jigawa State, Nigeria. Tel: 08035851872, Email: drajulugreatgod@ hotmail.co.za

Received: 9 May. 2016; Accepted: 20 Jun. 2016; Online Published: 27 Aug. 2016

\begin{abstract}
Background: There is a renewed interest in job satisfaction among healthcare workers including nurses in Africa and the West African subregion due to the perception that global shifts in the internal structures and employment practices are inducing changes in the ties that bind employees to their job. Therefore, it is necessary to examine various studies in order to establish an empirical base and utility for the theory of knowledge.

Objective: This paper reviewed some of the available literatures on factors affecting job satisfaction among nurses around the world with special focus on the African continent.

Methods: Electronic search of Medline, PubMed, Health Internetwork Access to Research Initiative (HINARI), and Google Scholar databases up to 2014 was carried out for studies which analyzed the factors affecting job satisfaction of nurses around the world, Africa and West Africa. Results: Although regional variations in levels of job satisfaction exist among nurses globally, there is more general trend of dissatisfaction and these are because of various factors related to the work environment. Nigerian nurses are generally more satisfied (as high as $92 \%$ ) with their jobs when compared with their colleagues in other African countries. Socio-demographic and socioeconomic variables do not affect job satisfaction as much as leadership styles, promotion and other features related to the work environment.

Conclusion: Strong leadership style is a probable reason why nurses in Nigeria are more satisfied with their jobs when compared with their colleagues in other countries even though they may work for longer hours or earn relatively less salaries.
\end{abstract}

Keywords: Leadership, Nursing Management, Hospital Practice

\section{Background}

The concept of job satisfaction and the assessment of job satisfaction started in 1911 with the research work of Frank Taylor [1]. However, job satisfaction research among health workers started on laboratory personnel in United States of America in 1971 [2]. Since then multiple researches on different categories of health worker like physicians [3], dentists $[4,5]$, nurses [6], physiotherapists $[2,7]$ and primary health care workers [8] in different parts of the world have been carried out. The implication of job satisfaction of health worker on patient care, patient satisfaction, improved patient outcome and overall health care delivery quality may have been the driving force [9].

Job satisfaction has been defined in several different ways and a definitive designation for the term is unlikely to materialize. A simple or general way to define it therefore is as an attitudinal variable [10]. He defined Job satisfaction as simply how people feel about their jobs and different aspects of their jobs. It is the extent to which people like (satisfaction) or dislike (dissatisfaction) their jobs.

According to Sousa-Poza and Sousa-Poza, if work-role outputs ('pleasures') increase relative to work-role inputs ('pains'), then job satisfaction will increase [11].

Job satisfaction is also defined as being a function of the perceived relationship between what one wants from one's job and what one perceives it is offering, influenced by the person's unique circumstances such as needs, values and expectations [12]. Locke defined job satisfaction as the pleasurable or positive emotional state that results from the appraisal of one's job or job experience [13].
Job satisfaction is a complex function of a number of variables. A person may be satisfied with one or more aspects of his/her job but at the same time, may be unhappy with other aspects related to the job [14]. There are different aspects to job satisfaction: job satisfaction is an emotional response to a job situation; job satisfaction is determined by how well outcomes meet or exceed expectations; and it represents several related attitudes such as those prompted by the work itself, pay, promotion opportunities, supervision and co-worker integration [15]. Essential to the concept of job satisfaction are the attitudes, emotions and feelings about a job and how these attitudes, emotions and feelings affect the job and the individual's life [16]. Willem et al. [17] defined job satisfaction in two categories; from a global approach and from a factors approach. Global job satisfaction is defined as the feeling and emotions generated by employees according to their work experiences or job environment [18].

Other theorists have viewed job satisfaction as a bidimensional concept comprising intrinsic and extrinsic satisfaction dimensions [19]. Intrinsic sources of satisfaction depend on the individual characteristics of the person, like the ability to use initiative, relations with supervisors, or the work that the person actually performs; these are symbolic or qualitative facets of the job. Extrinsic sources of satisfaction are situational and depend on the environment, like pay, promotion, or job security; these are financial and other material rewards or advantages of a job. Both extrinsic and intrinsic job facets should be represented, as equally as possible, in a composite measure of overall job satisfaction. This distinction, as described by Rose, relates to the double 
meaning of the word 'job': the work tasks performed and the post occupied by the person performing those tasks. The meaning of 'job' as a post or appointment is of primary importance. Every job is an instance of the employment relationship, embodying a contract (substantive or implied) to exchange an ability to work (labor, provide service, exercise ingenuity, direct efforts of others, etc.) for rewards (both material and symbolic). Of course, performing work tasks provides a stream of experiences, technical and social, that can energize psychosocial responses; any resulting data summarizing these reactions are indispensable. Nevertheless, such data must not be weighted higher than those concerning experience of the overt (or ostensible) contractual terms - above all, those concerning pay and job security [19].

\section{Objective}

There is a renewed interest in job satisfaction among healthcare workers including nurses in the West African subregion due to the perception that broad even global shifts in the internal structures and employment practices are inducing changes in the ties that bind employees to their job. While the concern for employee satisfaction in Africa may be high, empirical research on its correlates is insignificant. Most knowledge emanates from individual experiences and expert opinions. The few studies carried out are limited in the sense that they relate to studies in individual organizations, are carried out at regional level and utilized small samples. Therefore, there is need to examine various studies in order to establish an empirical base and utility for the theory of knowledge. This paper reviewed some of the available literatures on factors affecting job satisfaction among nurses around the world with special focus on the African continent.

\section{Methods}

A narrative literature review was carried out following electronic search of Medline, PubMed, and Health Internetwork Access to Research Initiative (HINARI), and Google Scholar databases up to 2014. Studies which analyzed the factors affecting job satisfaction of nurses around the world, Africa and West Africa were identified.

Search was carried out by one author in keywords like job satisfaction, factors, correlates, healthcare, nurses, leadership and dissatisfaction. A function extracting related articles as well as reference lists from research, reviews and editorials was utilized during the search process. The full version of the English-language analyzed articles and abstracts of most papers found were available during the selection process.

Literature involving observational studies, descriptive studies and prospective randomized controlled trials (RCTs) evaluating factors affecting job satisfaction or dissatisfaction, published in English language, were included.

\section{Results}

Table 1 has shown that nurses in Nigeria reported higher levels of job satisfaction when compared to their colleagues in other Africa countries. Table 2 shows various correlates of job satisfaction including leadership style, promotion and remuneration.

\begin{tabular}{lccc}
\hline Author & Study Type & Country & Job Satisfaction Rate \\
\hline Ugwa $^{[20]}$ & $\begin{array}{c}\text { Cross- } \\
\text { sectional } \\
\text { Cross- }\end{array}$ & Nigeria & $\begin{array}{c}87.5 \% \text { (Junior nurses) } \\
92.3 \% \text { (Senior nurses) }\end{array}$ \\
\hline Pietersen $^{[21]}$ & $\begin{array}{c}\text { Nepal } \\
\text { sectional }\end{array}$ & $54.29 \%$ \\
\hline Blaauw et al $^{[22]}$ & $\begin{array}{c}\text { Cross- } \\
\text { sectional } \\
\text { Cross- }\end{array}$ & Tanzania & $82.6 \%$ \\
\hline Blaauw et al $^{[22]}$ & $\begin{array}{c}\text { Sectional } \\
\text { Tshitangano }\end{array}$ & Malawi & $71 \%$ \\
Blaauw et al $^{[22]}$ & $\begin{array}{c}\text { Cross- } \\
\text { sectional } \\
\text { Cross- } \\
\text { Ugwa et al }\end{array}{ }^{[24]}$ & $\begin{array}{c}\text { South } \\
\text { Africa }\end{array}$ & 44 to 52.1\% \\
\hline sectional & Nigeria & $92 \%$ \\
\hline
\end{tabular}

Table 2. Factors affecting job satisfaction

\begin{tabular}{lccc}
\hline Author & Study Type & Country & $\begin{array}{c}\text { Job Satisfaction } \\
\text { Factor }\end{array}$ \\
\hline $\begin{array}{l}\text { Ugwa and } \\
\text { Ugwa }\end{array}$ & Cros] & Nigeria & Promotion \\
Ugwa $^{[20]}$ & Cross-sectional & Nigeria & Leadership style \\
$\begin{array}{l}\text { van der } \\
\text { Doef }^{[26]}\end{array}$ & Cross-sectional & East Africa & Promotion \\
Kekana $^{[27]}$ & Cross-sectional & $\begin{array}{c}\text { South } \\
\text { Africa }\end{array}$ & Remuneration \\
Erasmus $^{[28]}$ & Cross-sectional & Rwanda & Remuneration \\
\hline
\end{tabular}

\section{Discussion}

\subsection{Levels of Job Satisfaction among Nurses in Some Countries}

The levels of job satisfaction among nurses vary around the world. Ugwa in a study carried out among nurses working in a teaching hospital in north-west Nigeria reported that most of the nurses were satisfied with their jobs (87.5 and $92.3 \%$ for junior and senior nurses, respectively). Nurses with low job satisfaction levels find it difficult to provide quality patient care [20]. In Nepal, job satisfaction was found in $54.29 \%$ of respondents [21]. The researchers suggested that dissatisfaction among healthcare professionals is a cause for concern, given that job satisfaction has implications for the efficiency, effectiveness and sustainability of the organization.

Studies in South Africa reported that 44 to $52.1 \%$ of nurses were satisfied with their jobs [20, 21, 23]. Some of the authors stated that respondents were dissatisfied with staffing, availability of workplace resources, salaries, safety of workplace, career development opportunities, and working hours. It was therefore concluded that nurses' turnover may be attributed to their dissatisfaction with the quality of care rendered in an institution; autonomy; type of supervision; professional interpersonal relationships; salary; safety of workplace; staffing; career development opportunities; working hours/shift work; mission and purposes of the institution; availability of workplace resources and location of the facility (rural or urban).

Levels of Job satisfaction among nurses in Tanzania and Malawi has been reported as 82.6 and $71 \%$ [22]. South African nurses seem to have the lowest levels of satisfaction in most studies reviewed but Chirwa et al. [29] found that nurses from South African and Tanzania had higher mean job satisfaction scores than those from Malawi, Swaziland, and Lesotho. The low levels of job satisfaction among public sector nurses in South Africa has been confirmed in a number of studies [30-32] and a survey of primary health care nurses in rural South Africa also found high turnover intentions as $51.1 \%$ planned to leave their current job within 2 years [33]. A cross sectional survey of nurses from Tanzania, Kenya, and Uganda found lower levels of job satisfaction when 
compared with a European reference group and also that satisfaction was lower among public hospital nurses than those working in the private sector [26].

Although regional variations in levels of job satisfaction exist among nurses globally, there is more general trend of dissatisfaction and these are because of various factors related to the work environment [26, 34-37].

Nigerian nurses are generally more satisfied with their jobs when compared with their colleagues in other African countries. Ugwa et al. also observed that these nurses were also more satisfied with their jobs when compared with the doctors (92\% vs. $79.4 \%$ ) despite poorer conditions of service and stated that the reasons require more studies [24].

\subsection{Theories of Factors Affecting Job Satisfaction}

A number of theories have been formulated for the study and explanation of job satisfaction. These theories were postulated by researchers and psychologists following their previous studies in related areas and these will help provide insight into those things that affect job satisfaction.

The job characteristics theory of Hackman and Oldman proposed that job attitude and behaviors are affected by five core objective job characteristics, two of which include job frustration and anxiety at work [38].

Motivation theory stated that people are motivated when they expect that effect will result in good performance. There have been variants of the motivation theory notable of which are those of Katzell [39] and Herzberg et al. [40].

The expectancy theory is based on the fact that people will only be motivated to do things to achieve some goals to the extent that certain actions on their part will help them achieve the goals and thus are satisfied but if not are dissatisfied. In correlation with the above theory, Hackman and Lawler [41] found that only individuals who have high needs for fulfillment on the job are satisfied by having a job which provides the opportunities for such needs to be fulfilled.

Moreover, there is the equity theory which views motivation as dependent on the need for fair treatment [42] and the goal or intention theory which postulates that performance is determined by the goal to which an employee is committed [43].

\subsection{Factors Affecting Job Satisfaction}

Considering the important role of nurses in determining the efficiency, effectiveness and sustainability of health care systems, it is necessary to understand what motivates them and the extent to which the organization and other variables affect their job satisfaction. In a study of 350 nurses working in Aminu Kano Teaching Hospital, Kano, Nigeria, Ugwa and Ugwa [25] determined association between job satisfaction and certain sociodemographic and work variables. The authors concluded that promotion revealed a better correlation with job satisfaction when compared with other variables such as age, number of dependents, number of working hours, etc. [25, 44]. They concluded that nurses' job satisfaction may improve if they are promoted timely.

Promotion has been previously identified as a specific intrinsic factor that may improve nurses' job satisfaction [20, 45].

In South Africa, nurses were found to be generally dissatisfied with their jobs and remuneration, poor working conditions and organizational climate were strong predictors $[27,28,46]$. A study from Rwanda revealed that factors such as remuneration, opportunities for growth, working conditions, recognition, rewards, appreciation, and benefits and allowances could contribute to nurses' levels of motivation [47].

Some studies have revealed that although nurses satisfaction are usually affected by intrinsic factors such as promotion, the extrinsic factors which are aspect of job consisting of variables that relate to the workers' environment can minimize dissatisfaction with work if properly handled $[48,49]$.

Ugwa reported that socio demographic and work information had very weak correlations with job satisfaction and performance [20]. The author further posited that democratic leadership styles demonstrated a strong relationship with job satisfaction, whereas autocratic leadership demonstrated a very strong relationship with performance [20]. This is in line with previous reports [50, 51]. From the study in Ado Ekiti, Awosusi and Jegede [50] found no difference in employee satisfaction with leadership styles. Nurses who possess democratic, transformational, and transactional leadership features provide better conditions for their patients, and the satisfied patients bring satisfaction to the nurses [52].

Contemporary management believes that the satisfaction of nurses from their work is the result of rational management and has a strong link with proper leadership and motivation to healthcare organizations [53] leadership and job engagement [54]. Finally, job satisfaction for nurses has a high correlation with specific issues like occupational conditions or ethics $[55,56]$.

\section{Conclusion}

Job satisfaction in Africa is affected by leadership styles, promotion and remuneration. In Nigeria, leadership style has a very strong correlation with job satisfaction. Strong leadership style is probably the reason why nurses in Nigeria are more satisfied with their jobs when compared with their colleagues in other countries even though they may work for longer hours or earn relatively less salaries. This culture of excellence is worthy of emulation.

\section{Acknowledgements}

The authors wish to acknowledge the nursing staff of Aminu Kano Teaching Hospital for their supports.

\section{Authors' Contributions}

All authors contributed equally in the preparation of this paper.

\section{Conflict of Interest}

No conflict of interest has been declared by the authors.

\section{References}

1. Donuk B. The comparison of the job satisfactions of the sport managers who work private and public sectors. Selcuk Univ Sosyal Bilim Enstit Dergisi. 2009;21:179-85.

2. Ogiwara S, Araki H. Job satisfaction among physiotherapists in Ishikawa Prefecture, Japan. J Phys Ther Sci. 2006;18(2):127-32. doi 10.1589/jpts.18.127

3. Ofili A, Asuzu M, Isah E, Ogbeide O. Job satisfaction and psychological health of doctors at the University of Benin Teaching Hospital. Occup Med. 2004;54(6):400-3. doi 10.1093/occmed/kqh081

4. Saheeb B, Mafeni J. Job satisfaction among Nigerian dental practitioners. Niger Quarter J Hosp Med. 1999;9(1):42-6. doi: 10.4314/nqjhm.v9i1.12338 
5. Luzzi L, Spencer A, Jones K, Teusner D. Job satisfaction of registered dental practitioners. Aust Dent J. 2005;50(3):179-85. doi: 10.1111/j.1834-7819.2005.tb00358.x

6. $\mathrm{Hu} \mathrm{J}$, Liu H. Job satisfaction among nurses in China. Home Health Care Manag Pract. 2004;17(1):9-13. doi 10.1177/1084822304268154

7. Oyeyemi AY. Job satisfaction traits of Nigerian physical therapists Physiother Theory Pract. 2001;17(4):257-68. doi 10.1080/095939801753385753

8. Amoran O, Omokhodion F, Dairo M, Adebayo A. Job satisfaction among primary health care workers in three selected loca government areas in southwest Nigeria. Niger $\mathrm{J}$ Med. 2004;14(2):195-9.

9. Kaldenberg DO, Regrut B. Do satisfied patients depend on satisfied employees? Or, do satisfied employees depend on satisfied patients? QRC Advis. 1999;15(7):9.

10. Spector PE. Job satisfaction: Application, assessment, causes, and consequences: Sage publications; 1997.

11. Sousa-Poza A, Sousa-Poza AA. Well-being at work: a cross-nationa analysis of the levels and determinants of job satisfaction. J Socio Econ. 2000;29(6):517-38. doi: 10.1016/S1053-5357(00)00085-8

12. Lund DB. Organizational culture and job satisfaction. J Bus Ind Mark. 2003;18(3):219-36. doi: 10.1108/0885862031047313

13. Locke E. The nature and causes of job satisfaction in MD. Handbook of Individual and organizational Psychology. Chicago: Rand McNally; 1976.

14. Ghazali SSA, Shah IA, Zaidi SAA, Tahir M. Job satisfaction among doctors working at teaching hospital of Bahawalpur, Pakistan. J Ayub Med Coll Abbottabad. 2007;19(3):81-3.

15. Moodley P, Coopoo Y. Job satisfaction of self employed trainers and personal trainers employed at commercial gymnasiums: a comparative study. SA J Res Sport Phys Edu. 2006;28(2):105. doi: 10.4314/sajrs.v28i2.25947

16. Carrim NM, Basson JS, Coetzee M. The relationship between job satisfaction and locus of control in a South African call centre environment. S Afr J Labour Relations. 2006;30(2):66-81.

17. Willem A, Buelens $M$, De Jonghe I. Impact of organizational structure on nurses' job satisfaction: A questionnaire survey. Int J Nurs Stud. 2007;44(6):1011-20. doi: 10.1016/j.ijnurstu.2006.03.013

18. Lephoko CS, Bezuidenhout MC, Roos JH. Organisational climate as a cause of job dissatisfaction among nursing staff in selected hospitals within the Mpumalanga Province. Curationis. 2006;29(4):28-36.

19. Rose M. editor Disparate measures in the workplace... Quantifying overall job satisfaction. BHPS Research Conference, Colchester; 2001: Citeseer.

20. Ugwa EA. A cross-sectional study of job satisfaction and leadership styles among the nurses in Aminu Kano teaching hospital. Niger J Basic Clin Sci. 2014;11(2):114. doi: 10.4103/0331-8540.140363

21. Chaulagain N, Khadka DK. Factors influencing job satisfaction among healthcare professionals at Tilganga eye centre, Kathmandu, Nepal. Age. 2012;35(56):74.67.

22. Blaauw D, Ditlopo P, Maseko F, Chirwa M, Mwisongo A, Bidwell $\mathrm{P}$, et al. Comparing the job satisfaction and intention to leave of different categories of health workers in Tanzania, Malawi, and South Africa. Glob Health Action. 2013;6:19287. doi: 10.3402/gha.v6i0.19287

23. Tshitangano TG. Factors that contribute to public sector nurses' turnover in Limpopo province of South Africa. Afr J Prim Health Care Fam Med. 2013;5(1). doi: 10.4102/phcfm.v5i1.479

24. Ugwa EA, Muhammad LM, Ugwa CC. Job satisfaction among nurses and doctors in a Tertiary Hospital in North-Western Nigeria: a crosssectional study. Int J Hosp Res. 2014;3(1):11-8

25. Ugwa E, Ugwa C. A survey of job satisfaction among nurses and its correlate in a tertiary healthcare in Northern Nigeria. J National Accreditation Board Hosp Healthcare Providers. 2014;1(2):29. doi 10.4103/2348-6139.151294

26. van der Doef M, Mbazzi FB, Verhoeven C. Job conditions, job satisfaction, somatic complaints and burnout among East African nurses. J Clin Nurs. 2012;21(11-12):1763-75. doi: 10.1111/j.13652702.2011.03995.x

27. Kekana H, Du Rand E, Van Wyk N. Job satisfaction of registered nurses in a community hospital in the Limpopo Province in South Africa. Curationis. 2007;30(2):24-35. doi 10.4102/curationis.v30i2.1068

28. Erasmus B. Nursing professionals' views on the workplace. Curationis. 1998;21(4):50-7. doi: 10.4102/curationis.v21i4.676

29. Chirwa ML, Greeff M, Kohi TW, Naidoo JR, Makoae LN, Dlamini $\mathrm{PS}$, et al. HIV stigma and nurse job satisfaction in five African countries. J Assoc Nurses AIDS Care. 2009;20(1):14-21. doi: 10.1016/j.jana.2008.10.001

30. Pillay R. Work satisfaction of professional nurses in South Africa: a comparative analysis of the public and private sectors. Hum Resour Health. 2009;7(1):15. doi: 10.1186/1478-4491-7-15

31. Bester C, Richter E, Boshoff A. Prediction of nurses' job satisfaction level. Curationis. 1997;20(4):59-63.

32. Uys L, Minnaar A, Reid S, Naidoo J. The perceptions of nurses in a district health system in KwaZulu-Natal of their supervision, selfesteem and job satisfaction. Curationis. 2004;27(2):50-6. doi: 10.4102/curationis.v27i2.976

33. Delobelle P, Rawlinson JL, Ntuli S, Malatsi I, Decock R, Depoorter AM. Job satisfaction and turnover intent of primary healthcare nurses in rural South Africa: a questionnaire survey. J Adv Nurs. 2011;67(2):371-83. doi: 10.1111/j.1365-2648.2010.05496.x

34. Hart P. The nurse shortage: Perspectives from current direct care nurses and former direct care nurses. Peter D Hart Research Associates The Federation of Nurses and Health Professionals. 2001:20.

35. Lundh U. Job satisfaction among Swedish nurses and laboratory technologists. $\mathrm{Br}$ J Nurs. 1999;8(14):948-52. doi 10.12968/bjon.1999.8.14.6546

36. Suliman WA, Abu Gharbieh P. Jordanian nurses: job dissatisfaction and anticipated withdrawal from practice. Dirasat Med Biol Sci. 1996;23:76-87.

37. Fung-kam L. Job satisfaction and autonomy of Hong Kong registered nurses. J Adv Nurs. 1998;27(2):355-63. doi: 10.1046/j.13652648.1998.00527.x

38. Hackman JR, Oldham GR. Development of the job diagnostic survey. J Appl Psychol. 1975;60(2):159. doi: 10.1037/h0076546

39. Katz D. Morale and motivation in industry. 1949.

40. Herzberg F, Mausner B, Snyderman BB. The motivation to work: Transaction publishers; 2011.

41. Hackman JR, Lawler EE. Employee reactions to job characteristics. J Appl Psychol. 1971;55(3):259. doi: 10.1037/h0031152

42. Porter LW, Lawler EE. Managerial attitudes and performance. 1968

43. Vroom VH. Work and motivation: Robert E. Krieger Publishing Company; 1982.

44. Aiken LH, Clarke SP, Sloane DM, Sochalski JA, Busse R, Clarke H, et al. Nurses' reports on hospital care in five countries. Health Aff. 2001;20(3):43-53. doi: 10.1377/hlthaff.20.3.43

45. Herzberg F. One more time: how do you motivate employees? 1968 Harv Bus Rev. 2003;81(1):87-96.

46. Uys LR, Minnaar A, Simpson B, Reid S. The effect of two models of supervision on selected outcomes. J Nurs Scholarsh. 2005;37(3):2828. doi: 10.1111/j.1547-5069.2005.00048.x

47. Kamanzi J, Nkosi ZZ. Motivation levels among nurses working at Butare University teaching hospital, Rwanda. Afr J Nurs Midwifery. 2011;13(2):119-131.

48. Jayasuriya R, Whittaker M, Halim G, Matineau T. Rural health workers and their work environment: the role of inter-personal factors on job satisfaction of nurses in rural Papua New Guinea. BMC Health Serv Res. 2012;12:156. doi: 10.1186/1472-6963-12-156

49. Awosusi OO, Jegede AO. Motivation and job performances among nurses in the Ekiti State Environment of Nigeria. Int J Pharma Bio Sci. 2011;2(2):B583-B95.

50. $\mathrm{Lu} \mathrm{H}$, While AE, Barriball KL. Job satisfaction among nurses: literature review. Int $\mathbf{J}$ Nurs Stud. 2005;42(2):211-27. doi 10.1016/j.ijnurstu.2004.09.003

51. Giallonardo LM, Wong CA, Iwasiw CL. Authentic leadership of preceptors: predictor of new graduate nurses' work engagement and job satisfaction. J Nurs Manag. 2010;18(8):993-1003. doi: 10.1111/j.1365-2834.2010.01126.x

52. Wong CA, Laschinger HK. Authentic leadership, performance, and job satisfaction: the mediating role of empowerment. J Adv Nurs. 2013;69(4):947-59. doi: 10.1111/j.1365-2648.2012.06089.x

53. Hamama L, Tartakovsky E, Eroshina K, Patrakov E, Golubkova A Bogushevich J, et al. Nurses' job satisfaction and attitudes towards people living with HIV/AIDS in Russia. Int Nurs Rev. 2014;61(1):131-9. doi: 10.1111/inr.12074

54. Al-Ahmadi H. Factors affecting performance of hospital nurses in Riyadh Region, Saudi Arabia. Int J Health Care Qual Assur. 2009;22(1):40-54. doi: 10.1108/09526860910927943

55. Goldman A, Tabak N. Perception of ethical climate and its relationship to nurses' demographic characteristics and job satisfaction. Nurs Ethics. 2010;17(2):233-46. doi: 10.1177/0969733009352048

56. Kinzl J, Knotzer H, Traweger C, Lederer W, Heidegger T, Benzer A. Influence of working conditions on job satisfaction in anaesthetists. Br J Anaesth. 2005;94(2):211-5. doi: 10.1093/bja/aei035 